\title{
Experiences in the integration of children and young people of Polish descent in Germany. Empirical contributions
}

KEYWORDS

Germany, migrations, Polish immigrants, integration, children and youth

\begin{abstract}
The accommodation of children and young people of foreign descent to new life conditions and educational challenges abroad is a process that takes place primarily in the context of social interactions. The aim of the article below is to present selected experiences in terms of integrating schoolchildren of Polish origin in Germany. The author considers the presentation of school space as an integration microcosm of its own to be of particular importance. It is worth noting that the German educational system in the present form often discriminates against schoolchildren of foreign descent and limits the opportunities for further education. The author's own empirical verifications served as the research illustration in the text. The verifications, though carried out on a small sample, indicate some timeless trends among young Polish immigrants.
\end{abstract}

\section{Poles' migrations to Germany. Introductory notes}

Migrations are an inseparable element of the multicultural world. This area abounds in an increasing number of questions and doubts. There are increasingly more challenges and consequences both for the Other - an intercultural traveller and the society of the receiving country (Bera, Korczyński, 2012; Chutnik, 2007; Kawczyńska-Butrym, 2009). Questions such as problems of social \& cultural adaptation, psychosocial barriers to integration, the feeling of alienation and social distance are an inseparable part of migrants' experiences. Because of many reasons for migration, it seems important today to claim that it should be understood at least in social perception not only as a category, but also as experiences of concrete persons that illustrate certain tendencies and build the image of migrants' community in a given place in the world. 
Germany as an important destination for Polish emigrants. This direction of mobility has a rich tradition in itself. Although today the population of Polish descent is the second largest group of immigrants after the Turks in the Federal Republic of Germany, there is still a shortage of theoretical reflections and empirical inquiries on that subject, and new research problems arise in the course of time (Nowosielski, 2012).

In 2016 there was the $25^{\text {th }}$ anniversary of the signature of the Polish-German Treaty of Good Neighbourship and Friendly Co-operation. Reflections on Polish-German social, political or interpersonal relations fit perfectly into the jubilee year lasting on that occasion. Because one of the priorities concerning the presence of immigrants in the receiving country is their good integration with the host country, twenty five years of good Polish-German neighbourship is an excellent opportunity to bring up this issue. This was done by the Ministry of Labour, Integration and Social Affairs of the Federal State of North Rhine-Westphalia. It has recently initiated the publication of a transparent study on the integration of persons of Polish descent in this land, which is inhabited by the biggest number of Poles (MAIS des Landes NRW, 2016). The preface to the publication emphasises the visible need for exploring this field of knowledge, explaining that 'we have rather skimpy information about over half a million Poles in North Rhine-Westphalia' (MAIS des Landes NRW, 2016: 5). It was also indicated that members of Polonia inhabiting this area do not find it difficult to integrate; besides, their presence is almost unnoticeable.

Going beyond the borders of North Rhine-Westphalia, we must notice that there is a tendency to function in a "translucent" manner for the entire Polish community living in Germany, which is perceived on the outside as an immigrant group that is integrated very well with the rest of the society (Babka von Gostomski, 2010; Cichocki et al., 2011: 6). In this context, the progress of the integration process seems interesting from the perspective of the youngest immigrants of the first and second generation. Known through the prism of individual experiences, their life and education outside their parents' homeland provide valuable deeper insight into the functioning of Polonia in the Federal Republic of Germany, particularly because few research papers have been published in this field. It is worth mentioning that the German literature of the subject focuses largely on the social \& cultural adaptation of young immigrants, particularly schoolchildren, to life in German society. However, research on integration focuses clearly on the problem of Muslim children and young people as a group representing a distinctly different culture. Incomparably less space is devoted in this context to Poles living in Germany. 
The aim of the paper presented here is to describe selected experiences in the integration of children and young people with Polish roots in Germany. The author's own empirical verifications served as a research illustration; although they were performed on a small sample, they indicate certain trends prevailing among the young members of Polonia ${ }^{1}$. The recognition of the relevant fragment of reality was preceded by a necessary theoretical background, which is the basis of further considerations. The starting point was the identification of the largest groups of immigrants in the Federal Republic of Germany, with particular regard to the presence of the Polish community. The author described issues concerning strictly the integration of immigrants, pointing out the change of the paradigm of this concept that occurred along with the recognition of the Federal Republic of Germany as a migrant country. The topic of the German education system in the context of (dis)integration was also brought up.

\section{Largest groups of foreigners. The presence of the Polish migrant community in the multicultural German society}

According to the date of the Central Register of Foreigners (as on: 31 December 2015; German: Ausländerzentralregister - AZR), there are 9.1 million foreigners living in Germany, the largest immigration group being formed by the Turks (cf. Table 1). It must be stressed that the number of foreigners is the largest of those recorded since the introduction of the register in 1967. At the same time, office workers remark that official statistics are only the lower limit of the actual size of immigration in 2015; therefore, they are largely underestimated. Foreigners arriving in the Federal Republic of Germany are, on the one hand, refugees from conflict regions; at the same time, we can still observe regular economic immigration from new member states of the European Union (Statistisches Bundesamt, 2016b). The spacious arrangement of immigrants is irregular. It is, however, an irrefutable fact that people with foreign roots settle most frequently in West Germany and the capital.

\footnotetext{
${ }_{1}$ The paper contains references to selected fragments of results of the author's own research contained in the master's thesis: M. Pozorska (2008). Aktualne problemy integracji dzieci i młodzieży pochodzenia obcego w Niemczech na przykładzie sytuacji polskich imigrantów, a typewritten copy of the master's thesis. Poznań.
} 
Table 1. The largest groups of foreigners in Germany (as on 31 December 2015).

\begin{tabular}{|c|c|c|}
\hline Largest groups of foreigners in FRG & Year & Size of the immigration group \\
\hline Turks & 2015 & 1.5 million \\
\hline Poles & 2015 & 740,962 \\
\hline Italians & 2015 & 596,127 \\
\hline Foreigners (total) & $\mathbf{2 0 1 5}$ & 9.1 million \\
\hline Persons with a migrant background & $\mathbf{2 0 1 4}$ & 16.4 million \\
\hline
\end{tabular}

Source: Statistisches Bundesamt (2016a): 37.

The number of immigrants living in Germany is larger if we take into account the total community with a migrant background, i.e., the category of people with Migrationshintergrund ${ }^{2}$ (except for foreigners, they include also naturalised immigrants, second-generation immigrants, resettlers and late resettlers). In such case, as indicated by Mikrozensus 2014 statistical research, the group of people with foreign roots amounts to 16.4 million. It accounts for as much as one fifth of the entire society. However, only slightly more than half of them (56\%) have a German passport (Statistisches Bundesamt, 2015b). Here, it is worth emphasising the longterm character of emigration of first-generation immigrants. The average length of their stay in Germany is almost twenty two years.

Poles in Germany. The Polish migrant community in Germany forms a multi-generation mosaic. In the German migrant environment, these persons form a strong representation that amounts to 1.6 million according to Mikrozensus 2014. If we include - beyond formal issues - Polish-speaking persons or persons having cultural ties with Poland, the size of this population can be estimated at approx. 2 million (Nowosielski, 2009: 1).

In the history of mobility from Poland to Germany, in consideration of the period of historical breakthrough in Poland in the years 1980-1989 and subsequent years, we must distinguish the following waves of migration (Nowosielski, 2012: 10-11):

1. Emigration of late resettlers in the 1980s.

2. Solidarity emigration in the 1980 s for political reasons.

3. Pre-accession migrations, 1990-2003, most often for economic reasons.

4. Post-accession migrations after 2004.

\footnotetext{
2 A detailed definition of the category of persons with a migrant background can be found in Mikrozensus (Statistisches Bundesamt, 2015a: 5).
} 
The Polish immigrant group is not distributed evenly across federal states. As in the case of the entire migrant environment, Poles live most often in West Germany. It is necessary to point out the geographical concentration referring to a few federal states. As mentioned at the beginning, the leading position among federal states is occupied by North Rhine-Westphalia, with particular regard to the Ruhr. Three times smaller is the community of persons of Polish descent in Baden-Württemberg. Very popular areas are also Bavaria, Lower Saxony, Hesse and Berlin (Statistisches Bundesamt, 2015a: 148-151).

North Rhine-Westphalia ${ }^{3}$ with the capital in Düsseldorf is the biggest German land in terms of population. Consisting of 564,000 persons, the Polish community in this federal state is also the largest of the remaining immigrant groups. This question is raised by the authors of the aforementioned report concerning the integration of persons of Polish descent in North Rhine-Westphalia based on Mikrozensus, who state that this direction of mobility is still chosen by many Poles. In 2014, only the migration wave of Romans was comparable in terms of size in this federal state (MAIS des Landes NRW, 2016: 3, 5). The community of schoolchildren and students with Polish roots is large and counted in thousands: 'in the school year 2014-15, 13,115 Polish citizens attended (all kinds of) schools in North Rhine-Westphalia. Polish students are the second largest group of foreigners in schools, which means that they surpass students of Italian descent $(12,045)^{\prime}$ (MAIS des Landes NRW, 2016: 11).

\section{The recognition of Germany as an immigrant country. A change of the paradigm of the concept of integration}

Cultural, religious and national diversity in Germany is visible in all spheres of life. The large share of foreigners in the social structure of the Federal Republic of Germany is mainly due to post-war and successive migrations of people to countries of Western Europe for political and economic reasons. As Magdalena Szaniawska-Schwabe notes, 'this country has been one of the largest recipients of immigrants in the world' (Szaniawska-Schwabe, 2009: 3). This is confirmed by quantitative data of Eurostat - in 2010, FRG was the country with the biggest number of foreigners from among EU states (as on 1 January 2010).

\footnotetext{
${ }^{3}$ In this federal area, in the city of Münster, the author's own empirical verifications were carried out.
} 
For the last few decades, particularly since the end of World War II, large crowds of immigrants have flown into Germany, contributing to the post-war development of the country that was called an economic miracle.

Migrant workers were called gastarbeiters in West Germany (the former Federal Republic of Germany) and contract workers in the German Democratic Republic (GDR). Most immigrants came from Italy, Spain, Greece, Turkey, Portugal, Tunisia, Morocco and Yugoslavia (Bade, 2013). Foreign workers were supposed to perform the job ordered to them and return to their homelands. However, this idea proved wrong, and gastarbeiters contributed to a significant change in the character of the society. Germany was such an attractive destination for migrant workers that many of them wanted to build their future in this country. In the years 1960-1973, 14 million immigrants arrived in Germany for economic purposes, and approx. 4 million decided to settle there permanently (Segeš Frelak, 2012: 18).

In spite of the prohibition to recruit workforce from abroad (German: Anwerbestopp) introduced by Chancellor Willy Brandt's government in 1973, the number of foreigners did not decrease. Part of foreign workers did not leave; on the contrary, they brought their families along to Germany. Economic immigrants transformed into permanent settlers (Kwiecień, 2015: 82). The number of foreigners, particularly women and children, began to grow successively in West Germany.

At that time, the need to integrate foreigners was not treated as a priority and the issue of formal recognition of the status of Germany as an immigrant country was still regarded as a taboo matter in public and political debates for decades' (Szaniawska-Schwabe, 2009: 3). Elementary but inconvenient facts and the visible need to undertake integration activities were denied, as if the surrounding reality could do without them. In the opinion of Klaus J. Bade, a certain kind of social paradox occurred in Germany in the form of a migration situation existing without... immigrants (Bade 2007: 32, quoted after Filsinger, 2008: 6). However, regardless of politicians' opinions and moods prevailing in German society, the number of foreigners grew successively. As Michał Kwiecień notes, it was impossible to stick to the assumption that only 'rotational movements of the workforce' occur in the country (Kwiecień, 2015: 82). It is worth stressing that, according to researchers, there were objective and clear grounds for recognising Germany as a immigrant country as early as the 1970s. K. J. Bade thinks that even the year 1973 can be regarded as the symbolic beginning of the new order (Bade, 2013). Eventually, only at the end of the 1990 s and the advent of the $21^{\text {st }}$ century was the transformation of Germany into an immigrant country recognised for the first time in the post-war history and did the reform of the migration policy start (1998-2004) 
(Foroutan, 2015; Kwiecień, 2015). This was a breakthrough moment, the beginning of a change in the perception of economic immigrants, which was not always friendly. Their presence was not longer treated only as something temporary. Legal regulations were introduced successively and multidirectional activities aimed at integrating persons of foreign descent with the majority society were undertaken. ${ }^{4}$.This diametric change in the perception of the role and place of foreigners in Germany was to take place, at least theoretically, on the basis of dialogue and agreement. The changes aimed at the subjectivisation of migration issues were accompanied by a change in the paradigm of the concept of integration. From the beginning of the 1970s till the recognition of Germany as an immigrant country, it was understood only as a process based on the initiative undertaken by immigrants themselves, who joined German society by adjusting to the majority of citizens. The blame for failures in the progress of integration understood in this manner was also put on the shoulders of Others through indication of problems caused by them that resulted from personal or cultural differences (Foroutan, 2015: 3-4).

The $21^{\text {st }}$ century brought a new understanding of integration in Germany as a process involving joint efforts of immigrants and the receiving society along with relevant legal regulations and a cohesive migrant policy. Naika Foroutan stresses that the aim was to bring about the interaction of immigrants and original inhabitants in all spheres of social life: from education to political participation (Forou$\tan , 2015: 3-4)$. This new quality in the approach to integration is a certain kind of departure from the perception of this process in rigid categories of progress made only by the host society, which tended towards attitudes favouring the marginalisation and social exclusion of culturally different minorities. The concept of integration being pursued in FRG today focuses on the prevention of the formation of parallel societies, at the same time following the principle of 'helping and requiring from' immigrants (PAP, 2016). Justyna Segeš Frelak notes that two essential direc-

${ }^{4}$ Some important stages can be identified in the creation of a new direction of migration policy, such as (Filsinger, 2008: 6; Segeš Frelak, 2012: 20):

- Amendment of the Citizenship Act of 2000

- The Immigration Act in 2005, which is a comprehensive and modern regulation of immigration issues

- establishment of a central entity responsible for immigration issues: the Federal Office for Migration and Refugees

- the Integration Summit organised on the initiative of Chancellor Angela Merkel, with the participation of the most important German politicians, and a conference on Islam held as a manifestation of dialogue undertaken with representatives of the Muslim community in 2006

- the National Integration Plan adopted in 2007, containing over 400 various commitments

- support of the migration policy through the activity of foundations and societies (e.g., Bertelsmann Stiftung, Schader-Stiftung). 
tions of government activities can be identified here (Segeš Frelak, 2012: 20; cf. Dietrich and et al., 2011):

- integration through linguistic unity - pressure on the improvement of the command of German among immigrants, which should contribute to the equalisation of access to education and the increase of chances on the labour market;

- integration through naturalisation.

However, in the author's opinion, such an approach leaves too little space for issues concerning the ethnic identity of the arriving population and German citizens and their involvement in the process of becoming culturally and socially familiar with the different nature of immigrant groups (Segeš Frelak, 2012: 20). We must suppose that it is more difficult to initiate the dialogue of cultures with such an approach. Therefore, even though integration-oriented efforts in Germany engage much attention of the government and involve large costs, this area still requires new problems to be diagnosed and solutions to be sought.

It is worth reflecting on to what extent the Germans have already succeeded in this field. In order to accomplish this task, it will be useful to make a short insight into selected conclusions from two reports: an international report and a domestic report. The first of them is MIPEX (Migrant Integrations Policy Index) as an index of 38 countries $^{5}$ on 4 continents - an international system of comparison of state immigrant integration policies ${ }^{6}$. In the MIPEX 2015 report, the Germans rank $10^{\text {th7 }}$ with a score of 61 points (Huddleston et al., 2015). This position is good and can be regarded as a sign of progress, but, taking into account individual areas of integration and a very high share of immigrants in the population, 'there is still a long way to perfection,' as reported by the Deutsche Welle. 'In general, Germans make "slow but steady progress" with regard to granting equal rights to foreigners or providing support to immigrants, as indicated by the authors of the report' (Matzke, 2015). The country has the lowest score in the area of health policy: 43 points. Education leaves also much to be desired (47 points): because of serious deficits in this area, the German education system is, as Arkadiusz Stempin calls it, the 'Achilles heel of integration' (Stempin, 2013: 61).

\footnotetext{
${ }^{5}$ In European Union countries, Australia, Canada, Iceland, Japan, South Korea, New Zealand, Norway, Switzerland, Turkey and USA.

${ }^{6}$ The situation of immigrants is evaluated in eight policy areas (labour market mobility, family reunion, education, political participation, permanent residence, access to nationality, anti-discrimination and health). In each of these areas, a maximum score of 100 points can be earned, and then all scores are averaged together.

${ }^{7}$ Poland ranked only $32^{\text {nd }}$ with a score of 41 points (Huddleston et al., 2015).
} 
The second document, a report prepared upon the order of the plenipotentiary of the government of the Federal Republic of Germany for migration, refugees and integration and elaborated by the Institute for Social Studies and Social Policy and the Research Centre for Social Studies in Berlin, is a cyclic assessment of the degree of integration of foreigners with German society (Dietrich, Köller, Koopmans and Höhne, 2011). It suggests that German-born or naturalised persons of migrant descent participate most frequently in central areas of social life. This group of immigrants is accepted most strongly by the host society, which translates into educational success, success on the labour market or social involvement. It is an alarming result, which suggests that the German passport is decisive for the full participation of immigrants in the life of the dominant society. This concern is justified, because the discrimination of foreigners is a persistent problem in Germany. The term 'institutional racism' is even used in public debate (cf. Matzke, 2015). These issues are still a challenge for the multicultural society; such a view was expressed by the Germans in the German Marshall Fund (2014). Moreover, one third of respondents (34\%) agreed with the opinion that they are concerned about migrations from the European Union, and half of them (51\%) are concerned about migrations from outside the EU (German Marshall Fund of the United States, 2014: 10, 15). The perception of integration as the mutual interaction of the entire society is still a postulate that breaks a persistently very strong stereotype. This tone of discussion is reflected by an opinion expressed by Maria Böhmer, the plenipotentiary of the government of the FRG for the integration of foreigners in the years 2005-2013, during the Integration Summit in Berlin in 2012, according to which 'Germans need the culture of accepting immigrants' (Scholz, Dudek, 2012). At that time, a very important and clear message was communicated by politicians: that integration is a matter of the entire culturally heterogeneous society and persons of migrant descent 'play an important role in the "internationalisation" of Germany and help to meet the challenges of globalisation' (Scholz, Dudek, 2012). It was stressed that this task would be easier to accomplish if the access of immigrants to public positions is increased ${ }^{8}$; if this happens, issues concerning the community of foreign descent will gain proper status and its voice will eventually be heard in the entire state. Such sectoral change of the structure of employment is an ambitious goal of the German government and is called the driving force of integration (Dietrich, Köller, Koopmans and Höhne, 2011: 131). It is also one of the needs of the labour market, imposed by changes occurring in the structure of the demographic

\footnotetext{
${ }^{8}$ In 2010, the percentage share of persons of migrant descent in the public sector was 9.9\%, with foreigners accounting only for 4\% (Dietrich, Köller, Koopmans and Höhne, 2011: 133).
} 
population of the FRG and the ageing of society. The importance of this challenge is illustrated by a random example quoted by the plenipotentiary M. Böhme, who says that today in Germany 'only every fiftieth journalist has foreign roots, so it is hardly surprising that the subject of immigrants has so little coverage in the media' (Scholz, Dudek, 2012).

It is beyond all doubt that the recognition of the German state as a migrant country initiated the long-term transformation of models of thinking and operation and "domestication" of the ethnic diversity of Germans and the creation of relevant structures in the state. After years of neglect, integration proved to be a huge challenge possible to accomplish in the distant perspective of decades. Words must be followed by actions and decisions, and a change of German mentality is necessary.

\section{German school as a place of (dis)integration}

School plays an important role in the integration process because, as Halina Sowińska emphasises, the learning process itself takes place through social interaction. Teaching takes place in classes, i.e., in groups, which already guarantees the occurrence of processes important for development, such as communication, social control and activity around common goals, etc. (Sowińska, 2002: 93-95).

As many as one third of children and young people (5-15 years) from migrant families learn in German schools (Foroutan, 2015: 2). One fourth of fifteen-yearolds have foreign roots (Stanat, Rauch, Segeritz, 2010: 207). If we also bear in mind that the FRG is inhabited by immigrants coming from 194 countries of the world (Metzner, 2012), it becomes understandable that teachers are confronted with huge religious, cultural and ethnolinguistic diversity every day.

This diversity of students' community is not addressed properly by the diverse environment of teachers. It is monocultural and dominated by persons with German roots, who find it difficult to respond to all challenges and problems of a multicultural school. According to the report on the state of integration, persons of migrant descent are underrepresented in the German education system. For example, on the level of lower secondary education, foreigners accounted for $4.3 \%$ of teaching staff in 2010. It is, therefore, a very alarming signal for German education (Dietrich, Köller, Koopmans and Höhne, 2011: 132)..

Undoubtedly, education achievements of students are an indicator of the successful progress of integration on the school premises (Schymura, 2013), and an increase of immigrants' access to education is also one of the principles of the 
National Integration Plan in 2007. The integration of students in German schools is still a problematic issue that demands much attention, and success in this field appears to be a distant goal.

Aiming at the provision of equal chances in education is still one of educational priorities in Germany. There is still much to do in this field because, according to PIRLS (Progress in International Reading Literacy Study - German: IGLU), the diversification of students because of their migrant or native descent is a fact already on the primary school level (Schymura, 2013; Siegert, 2008).

The results of the Programme for International Student Assessment (PISA) are not better. The distance between teenagers coming from migrant and autochthonous families is maintained in further cycles of the PISA study. On the level of lower secondary education, differences in competences of allochtonous and autochthonous students become even more profound (Siegert, 2008). Therefore, students from migrant environments may feel harmed because of uneven access to education in comparison to their peers of native descent, suspend their education more frequently and find it more difficult to achieve educational success. Their school career depends largely on the social-economic status and the level of education of the environment, which, in turn, corresponds to their level of command of German language ${ }^{9}$ (Dietrich, Köller, Koopmans and Höhne, 2011).

The German education system does not favour integration. This is caused by the very early selection of students upon completion of education on the primary level. The choice of secondary school at this stage largely determines the further course of education. Students can basically select one of the three kinds of general secondary schools: Hauptschule, Realschule and Gymnasium, which is attended by best primary school pupils. Attending a given school opens or limits the way to further education, including academic education (example: Hauptschule). This is confirmed by data, according to which Hauptschule was attended by $28 \%$ of all students of foreign descent and only by $12 \%$ of students of German descent in 2008. Native Germans attend more frequently Gymnasium (40\%) and Realschule (26\%) (Statista, 2008). Children of persons with higher education are directed to Gymnasia more frequently. Social diversification in German schools in respect of migrant origin is stronger than in the United States (LPB-BW, 2009).

\footnotetext{
${ }^{9}$ Izabela Schymura remarks that the higher the level of education of parents, the higher the chance that children will climb successive steps of education successfully. The education of parents also impinges on their ability to use German language and better communication in the language of the country of immigration and increases the probability of functioning both in the receiving culture and in the culture of the country of origin in the student's home (Schymura, 2013: 42).
} 
Nevertheless, it is worth noting that the internal reality of the migrant student community is heterogeneous. As Manuel Siegert indicates, it is possible to distinguish students with better and worse school performance, which translates into types of secondary schools being chosen. According to the study, students from Turkey, Italy, Serbia or Montenegro perform worse. They usually attend Hauptschule or special school. On the other hand, Polish, Russian and Croatian students achieve better results and attend Realschulen and Gymnasia more frequently. It is worth emphasising that their educational successes are equal to those achieved by German young people (Siegert, 2008: 4). In the case of students of Polish descent, the level of education of the environment has a large impact on their educational aspirations. The Representative Survey of Selected Migrant Groups 2006/2007 (Repräsentativbefragung ausgewählter Migrantengruppen - RAM 2006/2007) proved that foreigners from Poland show a high level of education among five largest groups of foreigners in the FRG. As many as $38.90 \%$ of Poles living in the FRG have a secondary school leaving certificate, which is referred to as Allgemeine Hochschulreife or Fachhochschulreife, or commonly as Abitur (secondary school graduation examination). The education of women deserves special attention. According to the quoted survey, $46.8 \%$ of female Poles completed the secondary level of education (Babka von Gostomski, 2010: 82). Thus, we can risk the statement that adult Poles appreciate education and, therefore, set a good example for Polish children and young people attending German schools.

\section{Methodological foundations of own surveys}

The research questions concerned the identification of experiences related to the integration of children and young people with German society and factors having an influence on the course of this process. The diagnostic poll method was used along with the questionnaire interview technique on a small survey sample, with the interview questionnaire used as a tool.

For the purpose of gaining information on individual opinions, attitudes concerning, e.g., adaptation in a new cultural environment, social contacts, respondents' attitude to their own cultural identity and the role of the Polish Catholic Mission in the development of friendly Polish-German relations, the method of individual cases was used, including the free (non-standardised) interview technique where instructions were adjusted to the type of the respondent and his/her experiences. 
The surveys were conducted in the years 2007-2008 in Münster in the federal state of North Rhine-Westphalia. Twenty four respondents were invited to give an interview. Among them, three categories of respondents can be indicated:

1. children and parents coming from the environment of Polish immigrants,

2. persons engaged in the pastoral, cultural \& educational and organisational activity of the Polish Catholic Mission in Münster,

3. German teachers, including the plenipotentiary for the affairs of students of migrant origin in one of the Realschulen in Münster.

The text contains references only to selected fragments of results of the author's own empirical verifications of timeless value referring to the subject-matter of the paper. Because of the small research sample, reported results and conclusions formulated on their basis constitute only a research illustration and must be treated with certain caution due to their lack of representativeness and only the contextual diagnosis of young immigrants' integration problems.

Characteristics of students covered by the surveys. The research sample within the poll covered twenty five students at the age of 11-18 years. Girls accounted for two thirds of respondents. Most respondents (84\%) represent the $2^{\text {nd }}$ generation of immigrants. Almost all students attend Gymnasium (others: Realschule $-23 \%$, Hauptschule $-4 \%$ ). Three respondents are primary school pupils. Respondents' parents are mainly persons who emigrated during the social \& political transformation period in Poland. The diagnosed persons attended classes run by the Polish Catholic Mission in Münster.

\section{Integration experiences from the perspective of children and young people. Selected topics from own surveys}

Competence in German. Language as a tool for communication and passing of meanings 'is a "transmitter" of broader culture and illustrates experiences of those who participate in this culture' (Kuszak, 2014: 39). Germans perceive the command of German language by immigrants as a prerequisite for successful integration, inclusion in social life and prevention of conflicts. Results of the German Marshall Fund poll (2014) show that it is treated as the most important requirement for the acquisition of nationality by $44 \%$ of Germans ( $44 \%$, whereas the European average is twice as low: 22\%), whereas respect for institutions and the law occupies only the second place (37\%) (German Marshall Fund of the United States, 2014: 27).

Even the basic command of the language of the receiving country allows the foreigner to participate gradually in everyday communication situations, and lan- 
guage awareness acquired in this manner domesticates the foreign cultural environment and builds a sense of community. As regards immigrants' children, Karin E. Sauer remarks that they acquire language through contact not only with adults, but also with peers. It is the language that paves the way for them to gain knowledge of the rules of social life of the host country. The author assumes that the more frequently children of migrant descent spend time with their peers from other countries, the better for the mutual integration (Sauer, 2007: 69). This is the basis for development of the ability to establish contacts and the proper context of the creation of new friendships and peer groups. From the perspective of the migrant student community, effective and competent communication in German is the basis of educational success.

Most of the children and young people who took part in the qualitative survey in question admitted that they communicate freely in German. Slightly more than two thirds of students (68\%) considered their competences in German to be very good. Every fifth person thinks that they are good. It is important to note that a majority of respondents-students (76\%) also admitted that they speak German most often when meeting their peers. They agreed that the command of German is the first step to the acquisition of foreign culture and the world in many new spaces.

From the perspective of parents participating in the survey, the mastery of German language by children is a milestone in the integration process. This is the straight way of establishing contact with peers. The diagnosed adults pointed out the easier situation of Polish children born in Germany who grow up in the German environment. In their case, the lack of language barrier results in a smooth "transition" through successive spaces of integration.

Results of own surveys fit into results of empirical inquiries covering persons of Polish descent in the FRG. It must be noticed that Polish immigrants are able to learn German, which is perceived favourably by the society of the receiving country. Results of surveys conducted under the German Socio-Economic Panel (SOEP) ${ }^{10}$ from the years 1984-2001 showed good language competences of the Polish migrant community in speaking and writing. On the other hand, results of the RAM survey (2006/2007) indicate that a majority of foreigners from Poland have a good or very good command of German. However, better scores were recorded for younger (at the age of 15-34 years) than older respondents (at the age of 35-64 years). In addition, high language skills of women from Poland were appre-

\footnotetext{
${ }^{10}$ Das Sozioökonomische Panel (SOEP) is a representative population survey that has been conducted in Germany every year sice 1984. It refers to activity on the labour market.
} 
ciated; the fact that many of them have a German-speaking partner was regarded as a favourable circumstance (Babka von Gostomski, 2010:105, 214-219).

With regard to linguistic diversity in Germany, it is also worth asking how respondents' teachers cope with this situation in the classroom. According to opinions of respondents, teachers of German or other subjects often acquire information about the grammar of native languages in their students in order to explain selected issues to them on the basis of the structure of their language. If a student finds it difficult to master German, he can attend compensatory lessons for all students (Förderunterricht). In two schools in Münster there are separate classes (Förderklassen) attended by students with an insufficient level of language skills in the regular class, where they have a chance to catch up with others.

\section{Friendship and social contacts}

Establishing contacts in new surroundings on emigration helps us to domesticate the unknown cultural environment. The advanced social integration process means maintaining informal non-institutionalised contacts with representatives of different groups and cultures, spending spare time with them and making friends. It is also the path where social capital is enlarged, because migrant networks become expanded.

If we take adolescents into account, the acquisition of broadly understood social competences in contacts with other people is an extremely intensive process at their stage of development. In early adolescence, the essence of friendship lies in joint initiatives and similarities in various aspects of action and thinking. At this stage, it is not a profound friendship based on loyalty, trust and understanding. Adolescents show a tendency to create groups of persons of similar age and with similar interests (Wagner, 1991: 46). It is an important period of formation of an adolescent's identity in specific conditions of emigration and the multicultural environment.

More than half of students covered by the survey (64\%) have most often persons of German descent in their peer group. Nearly one fourth (24\%) maintain contacts mainly with other Poles. The keeping of friendships with peers of Spanish and Russian descent was sporadically declared.

To what extent is mental distance present in Polish-German relations? Opinions on that subject were expressed mainly by adult respondents. It turns out that misunderstandings occur in this respect in interactions. Respondents said that their contacts with Germans lack openness, cordiality and spontaneity, warmth and familiarity and excessive distance is sometimes disturbing. Nevertheless, both 
parties try to establish a dialogue. The interviews contain statements (with regard to relations in the school area) that the current generation of German parents of school-age children is not open to building good relations with Poles.

I don't feel any antipathy in our child's class, just the opposite. We meet every six months. These are classroom meetings, where parents come and do something together with children, also in order for us to get to know each other better. It's another generation ${ }^{11}$.

As far as diagnosed parents are concerned, separation as a selected acculturation strategy was observed in individual cases. The dominance of negative emotions towards contacts with the majority environment and the restriction of mutual relationships were observed at that time.

'There is no German among my friends, I would not even like to have a German friend, it simply doesn't fit. The Pole and the German will never be brothers, I don't believe in Polish-German friendships.'

In a sense, the attitude of parents is transferred to children, who model adults' behaviours, alienate themselves from host culture and idealise the country of their origin, which is reflected by the quality of their contacts with German peers. Such was the case of an eleven-year-old girl, a Realschule student, who openly admits that she finds it very difficult to integrate among peers. She feels unaccepted because of the country of her origin, although she speaks German proficiently. Her parents systematically save money for the construction of a house in Poland. The eleven-year-old strongly hopes that her dream will come true some day and the whole family will move to Poland. She expresses her regret about being ill-treated by peers as follows:

'In Realschule they laugh at me that I'm from Poland and that I have no friend from Germany, only from Russia.'

It is worth mentioning that the factor strengthening the presented attitude is the situation in which a family treats their stay in Germany only as a temporary stage, which they justify with the lack of sense in expressing concern for positive relations with the German society. In this way, the need for integration is denied, although building a negative image of Germans and Germany in the family may have no real justification in everyday life. This is how a communication barrier is created and stereotypes prevail over common sense.

The author's observations suggest that respondents are more willing to attribute the tendency to separation to other Poles than to themselves and see that it is

\footnotetext{
${ }^{11}$ All fragments written in italics are authentic opinions of respondents.
} 
the origin of integration problems. They usually present themselves in good light as persons getting on well with the German society.

¿.. I know one family that alienates itself completely. These people don't like an$y$ thing here and complain about everything in Germany; they even say that school is bad. They have no contacts. This separation is almost pathological. The second family maintains only necessary contacts with Germans. Another family finds it difficult to function in the German society. When the mother organised her child's birthday party, she did it twice ... she thought that when Germans are invited, you can't talk freely, because it's impossible to speak Polish.'

Isolationistic tendencies quoted here appear only on the margin of the discussion on the functioning of Poles and persons of Polish descent in the FRG. As far as integration is concerned, the positive image of Polish emigration that can and wants to integrate with the majority society is prevalent among Germans.

School - the microcosm of integration. The diagnosed students function well in the German school system. Most respondents learn in Gymnasia, which offer a high level of education and open the door to higher education. A majority of these persons have no problems. According to opinions of German teachers, students of Polish descent along with autochthonous peers form a unified student community. They do not separate themselves from peers of other nationalities, and their command of German allows the didactic process to be conducted freely.

In the opinion of diagnosed adolescents, school creates a favourable climate for the integration and the subjective approach to the multicultural community of students and their families and guardians. It is worth mentioning, for instance, the initiatives addressed to students of various nationalities that were mentioned by respondents. This refers, for example, to the organisation of Christmas meetings in consideration of cultural differences. One of the female teachers express her opinion on 'Europa' - a programme completed in her primary school. Under this programme, various nationalities were presented and described for one week; it was also an opportunity to taste dishes from various countries. However, as German teachers reported, not all of the initiatives have become popular.

"Four years ago, a group called "Parents and teachers in school" was established in our Hauptschule. Unfortunately, few parents attend these meetings. The idea of this group was to give parents an opportunity to become better acquainted with one another. However, due to the low participation of parents, this initiative does not bring results.'

Another respondent, a female teacher, mentioned another form of support and integration addressed to parents with a migrant background who do not speak German. 
'We have created an evening German language course in our Realschule for these parents. Many courses of this kind are offered in the city. We have decided to include them in the offer of our school in order to have personal contact with parents of children of migrant descent.'

The plenipotentiary for the affairs of students of migrant descent in Realschule brought up the issue of including integration topics in school activities. In her school, they are covered most frequently during German lessons, because curriculum contents fit well into this subject area. It is an important didactic task, because the school is attended by a total number of five hundred students, $30 \%$ of whom have a migrant descent. The undertaken prevention activities are justified. The respondent also added that the class taught by her includes twenty eight persons who represent twenty two different nationalities.

It is worth stressing that, according to some respondents, the German school tries to address the needs of the multicultural student community resulting from their cultural and religious customs. There are, however, also situations where good intentions of teachers are not sufficient, and the need for co-operation on the part of parents arises. According to an opinion expressed by one of the teachers in Hauptschule, the biggest challenge is posed by Muslim students, and this problem is widely discussed in the literature of the subject (cf. El-Mafaalani, Toprak, 2011).

In our school we try to respect the beliefs and faith of our students and their families, so students (Muslims) are allowed not to come to school on days celebrated as holidays in Islam ... However, in the case of radical Islamic believers, girls can become married already at the age of 15, and such situations often happen. This is a result of the family's influence. Later such girls often simply disappear from school, stop their education and are isolated from their peers by parents.'

Moreover, respondents recognise difficulties in the integration of students of foreign descent in the school environment and point out their tendency to isolation from autochthonous students. In their opinion, this problem concerns Hauptschule in Germany. The primary reasons for these difficulties in integration that were indicated by respondents included skin colour, descent (most often Turkish) and too large classes. In schools of students covered by the survey there were cases of intimidation or ridicule because of a student's different nationality. However, these cases were incidental and the students covered by the survey feel generally safe. In spite of this, one of the mothers put forward the thesis that 'the more different nationalities in a school, the more dangerous'. The students point out the lack of exchange of cultural experiences. More knowledge about one another would prevent cases of racially motivated discrimination of students. One of the respondents, the father of a seventeen-year-old Gymnasium student, confirmed 
the commonly prevailing opinion that there are serious integration problems in Hauptschule and quite often in Realschule. These schools are attended by students representing various nations who often have serious learning problems. These persons often separate themselves from original inhabitants. The adoption of such an attitude does not help to build good relations within the student community. The son of the aforementioned respondent speaks very highly of Gymnasia, saying that these schools are free of disintegration problems, students achieve good results and have an excellent command of German.

$\therefore$... in the case of Realschule and Hauptschule, there is a catastrophe! No one likes one another and [students - M.K.] regularly play truant. They are aggressive, because when they get poor marks, they don't go to school, and when they aren't at school, their parents are angry with them. They can't cope with life! In Gymnasium and only here, there are no such people. I think that Turks isolate themselves most strongly.'

To sum up, it is necessary to stress once more that the current education system in Germany intensifies the condition in which the following dependency can be seen: the more "prestigious" type of secondary school offering education for students with better achievements, the fewer integration difficulties. Nevertheless, competencies of participants of the integration process in the field of German language play a decisive role in the successful progress of this process (Dietrich, Köller, Koopmans and Höhne, 2011). 17). Verifications showed that this position is also shared by the teachers' environment. The plenipotentiary for the affairs of students of migrant descent in Münster does not idealise the situation in Gymnasia for this reason. She believes that building a multicultural student community, even in the most difficult conditions, will be successful if an interaction of pupils in common language occurs. This is the basis for further actions. To confirm these words, this active teacher gives an example of her workplace: Realschule where the problem of isolation of immigrant minorities does not exist. 'This is certainly a result of children's good language level,' adds the respondent. 'Children get on with one another regardless of their nationality; they don't ask about it.'

The maintenance of Polish cultural identity in the family. The family where relations between members are appropriate is an irreplaceable area of integration (Sauer, 2007). Mechthild Bahlmann remarks that it is a certain "point of reference" and a haven of safety for young immigrants (Bahlmann, 2000: 66). According to respondents' answers, most of them try to maintain Polish traditions in their homes at least to a minimum extent and to hand them down to further generations. As they stressed, they attach highest importance to Christmas. Poles appreciate native customs on these days. During that time, many Poles leave to visit a family in the home country. The diagnosed parents admitted that Polish traditions arouse in- 
terest among their children's peers, who thus become carriers of tradition. When asked which tradition is cultivated in her home, one of the respondents answered:

'The Polish tradition, of course! Everything is like in Poland. The First Communion takes place in a Polish church in Münster. We spend holidays in Poland. During this school year my son's school organised a meeting "Christmas Eve supper in my country" and children told how Christmas is celebrated in their homes. My son brought wafer along.'

\section{The Polish Catholic Mission as the initiator of activities aimed at integration and maintenance of Polish cultural identity - the community as a "hotbed of new generations"}

The Polish Catholic Mission (PCM) is a specific centre of Polish identity and integration. In Münster ${ }^{12}$ it comprises a large group of Poles, and the beginnings of its activity as a Polish pastoral office date back to the first postwar years and are connected with the establishment of a Polish school and the arrangement of a chapel in which masses for Poles were celebrated.

It is worth perceiving the existence of PCM through the prism of various forms of help and support and pro-integration initiatives arising from pastoral and cultural \& educational activity, accompanied by openness to co-operation with other missions and representatives of various immigrant groups.

Within the scope of the Mission's activity, pilgrimages for young people of other nationalities to the Shrine in Telgte are organised every year. In St. Anthony's Church in Münster, where the office of the Mission is located, a parish indulgence is celebrated together with the Spanish, the Tamils, Arabian Christians and Germans, to which all Christian missions are invited.

It is worth noting Polish and religion lessons being conducted by PCM for various groups of children, depending on their age and the level of command of Polish. In the school year 2015-2016, these classes were attended by around eighty children. This Catholic community is certainly committed to building positive Polish-German relations and manages to stimulate activity among parents and students. Its activity gives Poles a sense of community in a foreign environment, allows them to maintain traditions and native customs and is like an exchange of information for many persons. At the same time, PCM brings Polish culture towards the multi-cultural society. Such perception of activity of this pastoral centre

\footnotetext{
12 The address of the official website of PCM Münster: www.polskamisjakatolicka.de.
} 
is reflected by an opinion of a female respondent who has been active in this community for many years:

'[We organise - M.K.] concerts and exhibitions, we invite various lecturers; we focus on cultural \& educational activity. It is important to communicate Polish tradition to Germans; it is not integration, but the presentation of our native customs and tradition to our "hosts", as, after all, we are strangers on this German land. We often organise meetings and lectures in German for German parishes, both for adults and children. PCM has rented a church from a German parish for years; every year we celebrate Corpus Christi together and have a common procession, and Mass is celebrated in both languages on this occasion. These are typical examples of integration.'

The respondent also emphasised that the Mission is always ready to help parents, particularly if their children have problems in school or show behaviour issues. Apart from that, PCM 'tries to co-operate with various institutions, such as youth centres, social welfare centre or Caritas.' Another Pole involved professionally in the Mission thinks that a very important role is played by a kindergarten run by her, where the youngest children 'become accustomed to Polish spoken language and make new friends. It is a hotbed of new generations; here children can speak without inhibitions and they are not afraid to do so.' Polish lessons sometimes attract also German children, who come there out of sheer curiosity. In this way, the German Polonia is not alienated, and its activity arouses respect and interest in a broader circle.

One of the responding priests sheds another light on the topic being considered by suggesting that, in pursuit of integration, Poles should not submit to assimilation, which may become destructive for them. The parish priest appeals: 'integration certainly has its purpose and should be, because it is worth becoming familiar with the culture of the country in which we live. But it should not turn into assimilation, the loss of traces of Polish tradition'. Another priest adds optimistically: 'I see that the perception of Poland in Germany has changed; we are in the European Union, and people talk in Polish more freely than in the past. Skills, conscientiousness and diligence are the most important things in school. I know from parents that Polish children are often one of the best students in their classes.'

Looking at the dynamic activity of the Mission in Münster and the good functioning of the Polish school, it is easier to reflect on integration in its broader sense, going beyond the walls of the Church. Children attending the Mission's Polish or religion classes, who are engaged in the common preparation and celebration of Polish national holidays and speak Polish in their homes on an everyday basis or 
have the only opportunity to do so in the community, are students of German multinational schools and are exposed to the integration process every day. In places such as the Polish Catholic Mission, various areas of competence are developed. The community supports the fulfilment of the important task of preparing young people for the role of multipliers of knowledge and attitudes connected with civic and intercultural education: persons with a stable sense of their own cultural identity, citizens of Europe and the world.

\section{Summary}

The integration of children and young people of foreign descent with the receiving society occurs in certain spaces, i.e., school, family, place of residence, friendship and all types of social contacts. Integration occurring in these areas helps to enrich their social and cultural capital (Sauer, 2007).

Results of the author's own surveys indicate that integration is not difficult for most of the responding students. The decisive factor is their good command of German and Polish, in which they often communicate in their homes and after lessons.

There can be no doubt that German schools are an important link in the education process for young people with Polish roots. They have an important impact on the formation of their further educational and professional path; they are the place of gaining experience in the multicultural environment and recognising one's own possibilities and predispositions.

The school system itself is heavily criticised in interviews with regard to the issues of integration. Children are assigned too early to various types of secondary schools with a diversified level of teaching, which often determines their future. It is certainly necessary to ensure the presence of persons of migrant descent in the teaching staff in order to guarantee the knowledge of language and culture of minorities present in school. The need to initiate actions promoting multilingualism and supported by an earlier diagnosis in a given school is also recognised.

In the author's opinion, building a student community above national divisions in the everyday life of school depends mainly on the teacher's individual approach to the student and the identification of individual problems. At this point, one can risk the statement that the teacher-pedagogue is the patron of the integration process. Any kind of progress is largely conditional on whether the teacher develops both his/her own intercultural competences and his/her pupils' competences in the course of the didactic \& educational process. 
The verifications completed so far allow us to have a more distant look at Polish-German relations, the perception of life in Germany by Poles and their commitment to the preservation of cultural distinctness, also in the youngest generation. The opinions of respondents (adult Poles) suggest that they do not want to be perceived as an assimilated cultural minority. Children and young people attending classes organised by the Polish Catholic Mission create a specific environment of young people. They build a community that openly admits its Polish immigrant background, at the same time being integrated with the German society both in and outside school. A new generation is growing in Polish homes in Germany - in comparison to the previous generation, it is more open to challenges concerning life in multicultural society and the globalised world. It does not manifest isolationistic tendencies, particularly with regard to awareness. It is very likely that the factor levelling any potential differences in Polish-German intercultural contacts among young people is, as indicated by Barbara Fatyga, the impact of mass culture. It is, however, a large topic that requires a new approach to the undertaken topic and further empirical verifications (Fatyga, 1997: 149).

\section{References}

Babka von Gostomski Ch. (2010). Fortschritte der Integration. Zur Situation der fünf größten in Deutschland lebenden Ausländergruppen. Im Auftrag des Bundesministeriums des Innern, Forschungsbericht 8 . Nürnberg.

Bade, K.J. (2007). Integration: Versäumte Chancen und nachholende Politik, „Aus Politik und Zeitgeschichte", Heft 22-23, pp. 32-38, quoted after: Filsinger D. (2008). Bedingungen erfolgreicher Integration - Integrationsmonitoring und Evaluation. Expertise. Bonn.

Bahlmann M. (2000). Aussiedlerkinder - ein (sonder-)pädagogisches Problem? Münster.

Bera R. Korczyński M. (2012). Dystans społeczny emigrantów polskich wobec „obcych” $i$, innych”. Lublin.

Chutnik M. (2007). Szok kulturowy. Przyczyny. Konsekwencje. Przeciwdziałanie. Kraków.

Cichocki, P. Götz M., Jarosz A., Nowosielski M., Kubiak P., Skrzypczak J., Tujdowski M. (2011). Polacy w Niemczech. Raport z badania. Ekspertyza Instytutu Zachodniego z 01/2011. Poznań.

Dietrich E., Köller R., Koopmans R., Höhne J. (2011). Zweiter Integrationsindikatorenbericht - erstellt für die Beauftragte der Bundesregierung für Migration, Flüchtlinge und Integration. Köln/Berlin.

El-Mafaalani A., Toprak A. (2011). Muslimische Kinder und Jugendliche in Deutschland Lebenswelten - Denkmuster - Herausforderungen. Berlin.

Fatyga B. (1997). Młodzi Polacy i Niemcy w kontakcie międzykulturowym. [In:] U progu wielokulturowości. Nowe oblicza społeczeństwa polskiego. Ed. M. Kempny, A. Kapciak, S. Łodziński. Warszawa, pp. 148-149.

Filsinger D. (2008). Bedingungen erfolgreicher Integration - Integrationsmonitoring und Evaluation. Expertise. Bonn.

Foroutan N. (2015). Die Einheit der Verschiedenen: Integration in der postmigrantischen Gesellschaft. „Kurzdossier Focus Migration“, No. 28, pp. 1-8. 
Kawczyńska-Butrym Z. (2009). Migracje. Wybrane zagadnienia. Lublin.

Kuszak K. (2014). Historia i współczesność zapisane w języku. „Kultura-Społeczeństwo-Edukacja”, No. 2 (6), pp. 39-56.

Kwiecień M. (2015). Polityka imigracyjna Niemiec. „Studia Ekonomiczne. Zeszyty Naukowe Uniwersytetu Ekonomicznego w Katowicach", No. 211, pp. 79-96.

Nowosielski M. (2012), Polacy w Niemczech. Stan i perspektywy badań. „Przegląd Zachodni”, No. 3, pp. 3-27.

Pozorska M. (2008). Aktualne problemy integracji dzieci i młodzieży pochodzenia obcego w Niemczech na przykładzie sytuacji polskich imigrantów, a typescript of the master's thesis. Poznań.

Sauer K. E. (2007). Integrationsprozesse von Kindern in multikulturellen Gesellschaften. Wiesbaden.

Schymura I. (2015). Zweisprachigkeit, Schulerfolg und Integration von Migrantenkindern mit polnischsprachigem Hintergrund, a typescript of the doctoral dissertation. Essen.

Segeš Frelak J.( 2012). Polska migracja zarobkowa do Niemiec po 2004 roku. [In:] Znikająca zagranica. Nowa polska migracja do Niemiec - perspektywa lokalna. Ed. A. Łada, J. Segeš Frelak. Warszawa, pp. 17-31.

Siegert M. (2008). Schulische Bildung von Migranten in Deutschland, Reihe „Integrationsreport“, Teil 1: Working Paper 13. Nürnberg.

Sowińska H. (2002). Procesy integracyjne w klasie szkolnej. [In:] Konteksty edukacji zintegrowanej. Ed. H. Sowińska, E. Misiorna, R. Michalak. Poznań 2002, pp. 93-95.

Stanat P., Rauch D., Segeritz M. (2010). Schülerinnen und Schüler mit Migrationshintergrund. [In:] PISA 2009. Bilanz nach einem Jahrzehnt. Red. E. Klieme, C. Artelt, J. Hartig, N. Jude, O. Köller, M. Prenzel, W. Schneider, P. Stanat, Münster/New York/München/Berlin, pp. 200-230.

Statistisches Bundesamt (2015a). Bevölkerung und Erwerbstätigkeit - Bevölkerung mit Migrationshintergrund - Ergebnisse des Mikrozensus, Fachserie 1 Reihe 2.2. Wiesbaden.

Statistisches Bundesamt (2016a). Bevölkerung und Erwerbstätigkeit - Ausländische Bevölkerung - Ergebnisse des Ausländerzentralregisters, Fachserie 1 Reihe 2. Wiesbaden.

Stempin A. (2013). Niemiecki model polityki integracyjnej. „Kultura i Polityka: zeszyty naukowe Wyższej Szkoły Europejskiej im. ks. Józefa Tischnera w Krakowie”, No. 13, pp. 56-70.

Wagner J. (1991). Freundschaften und Freundschaftsverständnis bei drei- bis zwölfjährigen Kinder. Berlin.

\section{Internet sources}

Bade K.J. (2013), Als Deutschland zum Einwanderungsland wurde, http://www.zeit.de/gesellschaft/ zeitgeschehen/2013-11/einwanderung-anwerbestopp (access: 27.03.2016).

German Marshall Fund of the United States (2014), Transatlantic trends 2014: mobility, migration and integration, http://trends.gmfus.org/immigration-2014/ (access: 25.05.2016).

LPB-BW (2009), PISA, IGLU, OECD-Jahresberichte und Ländervergleich der KMK-Bildungsstandards, https://www.lpb-bw.de/pisa.html (access: 27.03.2016).

German Marshall Fund of the United States (2014), Transatlantic trends 2014: mobility, migration and integration, http://trends.gmfus.org/immigration-2014/ (access: 25.05.2016).

Huddleston T. Bilgili Ö., Joki A.-L., Vankova Z. (2015), Migrant Integration Policy Index (2015), http://www.mipex.eu/ access (27.03.2016).

MAIS des Landes NRW (2016), Integracja osób pochodzenia polskiego w Nadrenii Pólnocnej-Westfalii. Wyciag z 4. opatrzonej komentarzem statystyki ds. imigracji $i$ integracji w Nadrenii Pótnocnej-Westfalii, https://www.msz.gov.pl/resource/bdbdc2b2-2f18-4825-a8a5-aadcd0a8fd50:JCR (access: 27.03.2016). 
Matzke M. (2015), Raport: Niemcy robia postępy w integracji cudzoziemców, http://www.dw.com/pl/ raport-niemcy-robi\%C4\%85-post\%C4\%99py-w-integracji-cudzoziemc\%C3\%B3w/a-18507227 (access: 25.06.2016).

Metzner I.D. (2012), WNiemczech żyjąimigrancize 194państwświata, http://www.dw.com/pl/w-niemczech-\%C5\%BCyj\%C4\%85-imigranci-ze-194-pa\%C5\%84stw-\%C5\%9Bwiata/a-16462700 (access: 05.04.2016).

Nowosielski M. (2009), Kondycja polskich i polskojęzycznych organizacji w Niemczech, "Biuletyn Instytutu Zachodniego", nr 19, http://www.iz.poznan.pl/news/96_nr\%2019.\%20Polacy\%20w\%20 Niemczech.pdf (access: 28.05.2014).

PAP (2016), Rząd Niemiec przyjął projekt ustawy o integracji imigrantów, http://www.polskieradio.pl/5/3/Artykul/1623772, Rzad-Niemiec-przyjal-projekt-ustawy-o-integracji-imigrantow (25.06.2016).

Scholz K.-A., Dudek B. (2012), Szczyt Integracyjny: Uczestniczymy w przekształcaniu Niemiec $w$ państwo imigracyjne, http://www.dw.com/pl/szczyt-integracyjny-uczestniczymy-w-przekszta\%C5\%82caniu-niemiec-w-pa\%C5\%84stwo-imigracyjne/a-15707077 (27.03.2016).

Statista (2008), Schüler mit und ohne Migrationshintergrund in Deutschland nach Schulform, http:// de.statista.com/statistik/daten/studie/156911/umfrage/schueler-mit-und-ohne-migrationshintergrund-2008-schulform/ (access: 27.03.2016).

Statistisches Bundesamt (2015b), Zahl der Zuwanderer in Deutschland so hoch wie noch nie, https:// www.destatis.de/DE/PresseService/Presse/Pressemitteilungen/2015/08/PD15_277_122.html;js essionid=FD501CC5E1A15E1463B2EE823D80F40E.cae3 (access: 27.03.2016).

Statistisches Bundesamt (2016b), Nettozuwanderung von Ausländerinnen und Ausländern im Jahr 2015 bei 1,1 Millionen, https://www.destatis.de/DE/PresseService/Presse/Pressemitteilungen/2016/03/PD16_105_12421.html (access: 27.03.2016).

Szaniawska-Schwabe M. (2009), Polityka imigracyjna Republiki Federalnej Niemiec, „Przegląd Zachodni”, $\quad \mathrm{nr} \quad 4$, http://iz.poznan.pl/plik,pobierz,1104,b007effdeb82b77f9ffad58c07655 9b4/4-2009-4-wybrany-art.pdf (access: 15.05.2016). 